\title{
Work Organization and Professionalization in New Media Industry - The Case of a Finnish Company
}

\section{Arja Haapakorpi}

Senior Researcher, Dr. Soc. Sc, University of Helsinki, Faculty of Social Sciences - HEINE Network, Finland ${ }^{1}$

\begin{abstract}
The article explores work organization in one new media company in a turning point of the business, in the 2000s. The company had changed from a small workshop to a medium-sized company in a few years. Growth, increasing competition, and uncertainty of profitability had altered the management and work organization. An approach of governance, aimed at efficiency and economy, was systematically implemented; the working methods were standardized, strict division of labor was carried out, and the professional qualifications were mainstreamed according to the business. The professional employees appreciated the new business-like management, but discovered that their opportunities for creative work were diminished with decreasing resources and a new project management pattern.
\end{abstract}

\section{KEY WORDS}

profession / work organization / new media / management / professional identity / professional competence.

\section{Introduction}

hen I started to study work organization and professionalization in new media business in the 2000s, my hypothesis was strongly influenced by studies that emphasized new and radical patterns to organize professional work in information and communication technology (ICT) companies. Work organization in ICT companies was claimed to be different from the traditional companies with hierarchies and strict division of labor. According to the studies, work organization in ICT companies was flexible and flat, with only minor hierarchies; the institutionalized division of professional labor work was substituted by teams consisting of expert employees from different disciplines and professional identities for company or team identification. Media reported that exiting processes were going on in new media companies: work organizations were claimed to be nonhierarchical workshops with loose labor division and innovative teamwork and flexibility of working hours.

In the research project, these hypothetical conceptions of the innovative organizational pattern and professional work mode were tested by studying work organization

\footnotetext{
${ }^{1}$ Arja Haapakorpi, Postdoctoral researcher, Dr. Soc. Sc, University of Helsinki, Faculty of Social Sciences, Network for Higher Education and Innovation Research, Higher Education Governance and Management - HEGOM, P.O. Box 26 (Teollisuuskatu 23), FIN-00014 University of Helsinki, Finland, E-mail: arja.haapakorpi@helsinki.fi
} 
in one Finnish new media company. The new media company, the research subject, was a medium-sized organization employing 100 professionals and the business was defined to provide "multimedia and Internet-based service solutions supporting customer's business activities" (the presentation in web sites and in brochures). In the data collection phase, the year 2000, the business sector was at a turning point as regards profitability, and the company being investigated also reacted to this.

I will start the chapter with a short research literature review and a description of the business developments to provide a conceptual framework for the study and an introduction to the study problem. After presenting the methodology and data, the findings will be reported and discussed with a short summary and conclusions.

\section{Mapping the case study in a literature review}

A conception of information society emerged in the 1990s (see Castells 1996), and it started varied theoretical discussions and empirical studies dealing with new economy and work. Scholars still continue discussing information society, although the boom has passed (see, for example, Pratt et al. 2007). Organizations of ICT or technology-based knowledge-intensive services (T-KIBS) and ICT work have been studied from divergent sociological perspectives. The researchers have been interested in management and organization of work; particularly team-based and project-based work management has been defined to be a new pattern to organize work and relations at work sites (see Christopherson 2002; Kolehmainen 2007; Pratt et al. 2007; Del Rosso 2009). A variety of subtopics are related to the concept of information society; in the studies of ICT professionals, developments of knowledge work have been explored (Kolehmainen 2007; Korvajärvi 2007; Pratt et al. 2007).

New media as an industry and as a profession is ambiguous, because it refers to ICT technology and to a new field of communication and art. A common definition for new media is "computer-based and interactive communication." It is in the boundary of technology, media, and art as it can be commercialized or used for nonprofit purposes, and new media professionals work in the fields of business, arts, and academy (Tarkka 2002a, 2002b). New media is both an ICT business sector and a field of communication and art.

During the data collection period, new media was starting to professionalize, but the institutional framework for that was weak. The concept of profession refers not only to a formal professional membership - a university degree and other institutional practices, relations, and symbols - but also to a position at a work site (Abbott 1988).

Institutionalized professions - particularly those in the fields of medicine and law have attained their legitimation with the help of legislation, but new media professionals, as a new grouping, strive for reinforcing their professional position at work sites (Abbott 1988; Haapakorpi 2009). In the 2000s, new media professionals were not an institutionalized profession, because the educational background and work territories were undefined and diverged. Strengthening the position was a challenge for the professional employees as employment opportunities and organizational patterns have a strong effect in their position (Christopherson 2002; Pratt et al. 2007).

In the sociology of organizations, the studies of ICT organizations and work can be categorized according to a political approach (Grint 1998, p. 113). The research 
traditions or epistemological approaches can be mapped in the continuum of a technocratic-critical axis. At one extreme, the technocratic pole, there are approaches that supply pragmatically oriented tools for improvement of organizational efficiency, and at the other extreme, there is the critical pole, often with radical perspective, interested in social effects of the organization upon its members and the society (Grint 1998, p. 113). Some research literature of management and organization of work in the ICT sector is technocratic by nature, in other words, the purpose is to provide useful information for management (for example, Clements et al. 2005; Garcia 2005). The critical perspective has been applied when studying conditions of working life in the frame of market dynamics and business logic. The environments of ICT companies have been insecure and fast changing, which has affected conditions of work. The critical perspective has been focused on poor opportunities for proper professional performance and development (Christopherson 2002; Pratt et al. 2007), precarious position of the professionals (Pratt et al. 2007) and unsatisfactory work organization or conflicts at the work sites (Karn 2008; Pratt et al. 2007), work-life balance (Kivimäki 2007), and gendered ICT technology (Korvajärvi 2007).

\section{Contextualization of new media developments and the definition of the research problem}

The ICT-based boom and hype produced brave ideas of working life developments in the 1990s and the leading hypothesis was that new economy takes the place of traditional industrial production (see Pohto and Wiren 2001, p. 3). According to the studies, work organization was claimed to be flexible and division of professional labor was assumed to be substituted by teams consisting of expert employees from different disciplines and professional identities were claimed to take the place of company or team identification (Depickere 1999; Kangasoja and Koistinen 1997; Tidd et al. 1997; Virtanen 1987). The phenomenon was called "post-professional organization of work" (Casey 1995).

The findings of the study did not comply with this hypothesis. There was a strong tendency toward traditional, hierarchical organization of work and clear division of labor and professional territories. A key for understanding these findings is to explore why the hypothesis was not met. Before starting the analysis of work organization and professionalization in the new media company, this topic will be discussed.

The company had been transformed from a small workshop to the medium-sized company in a few years. The data were collected in the 2000s, which was the turning point in the new media industry. New media as an art and an industry was young in the 1990s and a lot of innovations were produced; the company was founded at the beginning of the 1990s. The organizational form of the case company was simple (see Scott and Davis 2007, pp. 11, 131). It was a workshop with 10 to 20 employees and a flat organization with a loose division of labor. The year 2000 was the turning point in the business, as the companies started to become business-like and grow, in the environment of increasing competition. They started to make more profit.

To illustrate the state of the business, some information is presented. In the 2000s, there were 330 companies in the business sector. Forty-nine to hundred companies have started the business from the 1995 s to the 1998 s, and only $20 \%$ had a longer history. In 1999, 70-100 companies employed less than 10 persons and in 2001, less than half 
of the companies were small. In 2000, $5 \%$ of the companies employed over 90 persons, and in 2001, the proportion was $15 \%$. In $1997,79 \%$ of the companies made profit and in 2000, the corresponding proportion was 91\% (Pohto and Wiren 2001, pp. 8-12).

Efficiency and economy became important when the staff multiplied in the company. The growth, increasing personnel and competition, and the objective of profitability altered the management and organization work, which had been a collection of fragmented objectives and working methods. The growth and transformation of the environment directed the management to organize the work in a way which followed the institutionalized organizational model.

Kirsi Koistinen (2007) provides similar interpretations as her research also dealt with the turning point in new media business. She concludes that the researchers of ICT work anticipated that the new, more innovative forms of work were about to replace old industrial and standardized ways of work. In her study, only minor changes to established organizational forms were seen and many of the independent companies faced great difficulties when they tried to survive the rapid changes in the products and production forms in the emerging field. Engeström and Ilmarinen (2001) also found similar developments in their study dealing with a new media company during the same period. The studies carried out in the 1990 s, reporting the radical innovations of work organization in ICT companies, overestimated the developments in ICT work organizations and the increase of ICT-based work. Olli Heikkilä claimed that there was a collective error in assessment in respect to these developments (Pohto and Wiren 2001, p. 3).

This article and the above-mentioned studies have analyzed the particular historical developments of new media business. These new media companies, as they have been described in these studies, do not exist anymore. They have mostly been amalgamated into big ICT and media companies and the new media profession has been converged as ICT and production have been transformed.

In this article, the objective is to study the pattern of organizing professional work in one new media company in the framework of the turning point of the business. The article will respond to the following research questions.

- The management's objective was to increase profits and promote effectiveness of the company. How was this aim implemented in work organization? How was professional labor organized?

- The professional competence and position of the employees was not yet institutionalized in the labor market. How did work organization affect professionalization of the occupational groups?

\section{Methodology and data}

The methodological approach was qualitative and grounded theory was applied. The data consisted mainly of interviews. The interviewees were chosen by the personnel manager. Thus, it is probable that the interviewees were more positively oriented toward the management than the employees on average and it can be assumed that the most critical issues may have been overlooked. However, the interviews also contained critical and contradictory perspectives. The themes were loose, which provided the interviewees with the opportunity to define approaches and topics from their own interests. The 
themes in the interviews were motives for work and career, work orientation, management of the company, work culture, work organization, and the relationship between work and leisure. The complementary data were the annual report of the year 2000, brochures for customers, and company magazines.

The findings of this research are based on one company in the business sector and, thus, they do not provide complete evidence for telling the whole truth of new media business in the 2000s. Diverging findings and interpretations by the other scholars are possible and probable. In addition, the literature review reported slightly diverging developments on new media across the nation states. However, the studies focusing on the similar subject, the new media companies in the 2000s, support the findings of this study.

The purpose was to get multidimensional data from the group being interviewed, and the group consisted of different professional groups. Ten people were individually interviewed: one personnel manager, two graphic designers, one audio-video designer, two programmers, two scriptwriters, and two project managers. In this article, the content provider category contains the groups of graphic designers, audio-video designer, and scriptwriters. The interview of the personnel manager focused on the issues and themes dealing with the company; her perspective was based on her position between the layers of management and employees. The rest of the interviewees focused mainly on their own work. The ages ranged from 25 to 47 years; the programmers and the audiovideo designer were male; the personnel manager was female. In the groups of graphic designers, scriptwriters, and project managers, the share of men and women was 50:50. Most of the interviewed persons were university and polytechnic students and only some of them had completed their degree, which was common in new media companies. They had studied media studies; data processing; literature and arts; social sciences, administration, and philosophy.

The interviews of the personnel manager, the project managers, and the programmers and content providers (the graphic designers, the audio-video designer, scriptwriters) were analyzed in separate units, because the issues being discussed diverged to some degree. This was related to their differentiated position in the division of labor and their relation to customers and management. The programmers and content providers carried out their tasks rather independently with their half-institutionalized professional competence. The project managers coordinated project teams and negotiated with the customers, which strongly suggested a work-related dependence on them. The position of the personnel manager was rather close to the management, although she was not in the core of decision-making. The project managers and the content providers and programmers identified themselves as employees.

The data were analyzed applying grounded theory, which supposes a data-based theoretical conceptualization. In practice, the theoretical construction is based on the interaction between the data analysis and the theoretical frame of the researcher (Strauss and Corbin 1998).

The core category was "the tension between the company's interest in efficiency and the professional employees' identity based on creativity.” This category collected a very dense body of data, which consisted of subcategories and their subcategories. The grounded theory includes a variety of category types and some of these types did not provide the analysis with satisfactory tools. Because of that, I amalgamated the categories of causal, structural, and intermediate conditions into one category representing the 
relation to organizational environment as it was not meaningful to separate them (the causal, structural, and intermediate conditions) in the analysis. The category was called "from hype to profit making."

\section{Findings}

\section{Governance}

With the grounded theory, concepts were constructed on the basis of the data analysis in interaction with the theoretical approaches supporting the analysis. In this process, the hypothetical approach of the new, radical ways to organize work in ICT companies was substituted for a new conceptual approach. The core category and the category representing the relation to the organizational environment, based on the data analysis, provided conceptions for constructing the theoretical framework. "From hype to profit making" category collected the data based on the transformation in the environment and the company's reaction to it. It started the generation of the concept "governance," as in the company, the objective of profit making was implemented as a streamlined and efficient work organization. The concept was further elaborated with the category "the tension between the company's interest in efficiency and the professional employees' identity based on creativity." "The tension" highlighted the character of the work organization as the company's interest in efficiency referred to streamlining and standardization.

Governance is a conceptual approach, which focuses on the mode of thinking and action related to the objectives of efficiency and economy. The idea of "governmentality," generated by Michel Foucault (1991), affected the theoretical frame and the concept "governance" was developed on the basis of it. Governmentality is a historically constructed way of analyzing and acting, which permeates the society and with which people aim not only at adapting to the world but also at actively channeling their activity toward desired goals. There are at least two Foucaultian definitions of governmentality: "a collective mental state" (Dean 1999, p. 16) and "a way of life" (Rose 2000, p. 283). Governmentality is not a theory particularly for organizational studies, but rather a conceptual approach to modern society and existence. However, it has been applied on working life studies, because it provides analysis with theoretical ideas related to the modern society (see McKinley and Starkey 1998). Work organizations are especially the sites where the methods and constructions of governmentality are practiced (see Rose 2000). In modern work organizations, the logic of efficiency supports the streamlined, efficient, and standardized mode of action. This theoretical framework provided the analysis with a deeper sociological view than organizational theories, because it explores new ways to organize people, life, and oneself.

According to Jackson and Carter, two perspectives of governmentality have been applied in working life studies (1998). The first derives from governmental rationality of controlling populations, being a whole series of specific governmental apparatuses and a whole complex of "savoir" (Foucault 1979). In working life studies, these populations are limited by organizational boundaries, but the idea of governmentality is similar. The "savoir" refers to forms of government, which have a logic of truth legitimizing them. Governmentality is a way of thinking and a set of practices, which makes direct control 
useless. The desirability of employees obeying the pattern of a company is legitimated by the work organization mode based on the economic principle. The second perspective refers to the particular mind set of governmentality, a mental state (Jackson and Carter 1998), which is close to Michel Dean's concept for governmentality.

"Governance" as the concept applied here is a particular, limited version of the concept of governmentality; it refers to a way of thinking and a set of related practices. The objectives of effectiveness and economy lead to streamlining and financial management, which are the ways of thinking and patterns for action striving for effectiveness and economy. As governance is a particular way of life or a mind set, it is also realized by individuals, in their thinking and action. Self-governance refers to self-control and self-design.

\section{Streamlining and financial management}

The main dimensions of governance are streamlining and financial management.

Streamlining was realized by applying a matrix method of work organization in the company: the concepts follow the definitions of Scott and Davis (2007, p. 131). The employees and activities were differentiated into professionally specialized departments. Work-assignments from customers were carried out in project teams, which consisted of professionals having diverging professional competence: experts in graphic designing, audio-video designing, programming, or scriptwriting. The project managers were responsible for coordinating and managing the project teams. One programmer described the organization as follows:

'The organization is two-fold. First, the organization of professional groups constitutes the structure of the company. Second, the project organizing is temporary, consisting of teams of professionals representing different competences.' (male, programmer).

The division of labor was crucial for the institutionalization of work practices. It complied with the general model of job descriptions in new media business (Pohto and Wiren 2001), which created commensurability. The job descriptions were established and related to each other, which promoted institutionalization of the intra-organizational and extra-organizational relations. Once professional work territories had been defined, the structure and processes of the organization became more transparent and controllable.

Studies dealing with ICT organizations often claim that teams and projects are the new ways to organize work processes and relations (see, for example, Christopherson 2002; Koistinen 2007; Kolehmainen 2007; Pratt et al. 2007; Del Rosso 2009; Tidd et al. 1997). These ways are often considered to promote innovation and learning (see, for example, Tidd et al. 1997). However, a team-based and project-based work organization sometimes supports traditional relations and work patterns at work sites. A particular pattern for organizing work is not a guarantee for innovation as the innovativeness depends on the implementation method (see Niemelä 2008). A similar remark has to be made with respect to the matrix organization. This organizational model is assumed to be appropriate for promoting flexible adhocracy, in particular when the environment is complex and dynamic (Mintzberg 1989). The organizational model can promote flexibility, but human action is required for realising it. 
In the case company, streamlining provided methods for fluently governing the work organization. The methods and practices were standardized and the projects were carried out following a similar model of project management, which was controlled by the project managers. Striving for profitability had directed the company to comply with business-like patterns. The studies aiming at promoting profitability in ICT business often recommend standardization of work processes (see Garcia 2005).

Financial management consisted of both quantitative and qualitative methods. Measuring and evaluating time, space, and activities were aimed at commensurable and controlled work, which provided better opportunities for planning and evaluating. In this study, the most often used method for financial management was resource allocation for the project teams, estimating and measuring the time and labor needed for the project teams. The knowledge and information of the activities, costs, and income were systematically collected and applied. According to Alvesson and Kolehmainen, the elaborated methods for financial management are not uncommon in ICT companies (Alvesson 1995; Kolehmainen 2007): ICT tools provide controlling methods for the whole production chain. One interviewee described his current work as follows:

'This job is totally different from the previous job I had; there is constant budgeting and calculating. Everything is estimated; these hours for this project and these for that. Processes are defined beforehand. All the activities are calculated.' (male, scriptwriter)

\section{Problems with customers and project management}

The management had developed a project management model to improve customer service and project management, and the goal was to increase efficiency. With the model, the working methods were streamlined and the control improved. In the customer brochure, the model was presented as follows: 'The chief of project management believes that streamlining the project processes improves the cooperation and interaction between the company and the customers.'

However, the controlling capacity of the model was not complete as it could not prevent unexpected problems. Similar findings of the project management have been made by other researchers (Beirne et al. 1998; Karn 2008; Pratt et al. 2007). The project management model was inappropriate for small or particular projects or with the customers with particular orders or expectations. The projects sometimes fell behind schedule, which disrupted the total management of the projects. In addition, the budgets were sometimes exceeded and the customers did not follow the agreements and instructions. One interviewee narrated his work:

'And the problem is that the customer does not make the decision what they want, and we constantly have to negotiate. And the project is delayed and delayed and the team members do not understand, why it takes so much time and why we have to do it again and again' (female, project manager).

Although the idea of efficient governing is rather common in work organizations, the logic and, thus, the applied techniques are different. The ideas or purposes related to the techniques are not easily understood from the outsider's viewpoint, and, thus, the 
practices are not meaningful to the outsider. The customers did not always follow the instructions given from the company as their decision-making related to the work assignment complied with their own needs and schedules.

The model of project management supported the professionalization of the personnel as with the division of labor, the employees with particular job descriptions had their particular work territory on the project-based teams. On the other hand, it did not supply opportunities for professional collaboration and development. The professional employees on the team carried out alone and independently their tasks, which reinforced professional territories and the boundaries between them. Because of the economic reasons, the team worked together only at the beginning of projects. The poor resources for multi-professional team work did not provide them with learning opportunities. Pratt et al. (2007) report similar findings; however, they have discovered that opportunities for learning and proper professional performance vary according to the market niche with different prospects for profit making.

\section{Personnel management and control of professional competence}

The standardization of working methods and division of professional labor were supported by the personnel management. The personnel management complied with the objectives of efficiency and economy by applying them on the personnel policy. The personnel management, despite working on "human issues," follows the logic of efficiency and economy (Lawler 2000; Townley 1998). The aim was to recruit and keep personnel that promoted profitability. According to the annual 2000 report, professional competence was defined as follows: 'The strong increase of business was supported by promoting adequate competence of the personnel.'

Appropriate recruitment policy, intra-organizational training, and standardized working methods promoted target-oriented competence. The required qualifications followed the professional system of disciplines; the institutionalized knowledge bodies were supposed to fit in the division of work and professional job descriptions. Job descriptions and qualifications were divided, categorized, and organized following the system of disciplines of higher education. The qualifications related to disciplines were expected to contribute to the labor division. Qualification related to institutionalized disciplines was prescribed as the recruitment requirement even for the new job descriptions: for example, university studies in literature or communications for scriptwriters.

Before the transformation into an institutionalized business enterprise, the professional job descriptions and the professional qualifications were rather loose. The authorities of new media arts defined the expertise to be in-between institutionalized disciplines and regarded it as a special convergence of media and contents (see Tarkka 2002a). In the late 1990s, new media productions in business and arts were interconnected, and new media experts carried out their projects in both territories. Arts, business, and technology were intertwined and presumed each other. New media culture was expanded in market and market took advantage of media culture. For example, new media experts in business and arts participated in the same festivals and competitions. Pieces of new media art were considered merits in the new media companies (Tarkka 2002a, 2002b). However, the more business and arts in this industry have differentiated, the less there are opportunities 
for this interconnection. In business enterprises, the production has to be fast, whereas artistic production requires time (Tarkka 2002a).

In addition to the mastery of a discipline, qualification for organizational adjustment was considered important. Appropriate professional competence, willingness to accept training, and adjustment to the company spirit were the criteria in recruitment. Higher education of the job-seekers provided information about their adjustment and professional competence: it suggested a conforming and extrovert employee. The personnel manager put it this way: 'A suitable person for our company has average intelligence and proper education. He/she has to be interested in this business, because the field is quite new. He/she has to fit in the "band" and be open and well-adjusted with an average personality.'

Intra-organizational training and particular methods for organizing work were inclined to develop uniform quality of professional competence. Professional competence of new employees was often insufficient and the intra-organizational measures were aimed at promoting professional skills. The professionally differentiated departments were supposed to disseminate the competence of the experienced professionals to recently recruited young employees. The skills and knowledge of the senior professionals were supposed to be integrated into an organizational competence by promoting collegial learning and intra-organizational training. In ICT companies, learning by doing - in either informal or more organized way - is common, because the technology is particular and the quality of expertise is inclined to companies (see Kolehmainen 2001, pp. 42-43, 2007). The standardization of competence was crucial for the project management, because insufficient competence delayed projects and there was a risk of uneven work quality.

The teams were temporarily established and they were broken off when the project was finished. The purpose was to prevent the specialization of the young professionals as they could not develop deep professional competence which permanent, collaborative teams would have provided them. The specialization would open up for them good positions in labor market negotiations. The personnel manager strove to control the competences of the professionals.

'The basic rule is that no-one specializes. If specialized professionals leave the company, much of the know-how is lost. We break up teams, when the production is done, and then we establish new ones. That is one method to keep the competence uniform.' (female, personnel manager).

This phenomenon is also recognized in other studies. In new media companies, the lack of learning opportunities is not unusual and even a shortage of formal education is reported (Pratt et al. 2007). Pratt, Gill, and Spelthann claim that poor employment contracts maintain the lack of training opportunities and competence development as the short-term contracts and extremely limited resources do not promote learning and a good quality of work (Pratt et al. 2007).

According to the customer brochures, the specialization of professionals was slightly emphasized: 'For each production, the most appropriate professionals are chosen.' When professional services are marketed, professional specialization and tailoring are often emphasized, although the services might be standardized due to the tight competition. 
The standardization of competence institutionalized working methods and the division of labor; that is, the control of competences and qualities supported governance. The standardization provided the company with business credibility as institutionalized competences and professional job descriptions indicate stability and reliability for customers. The personnel management stressed the control of professional competence: the goals for recruiting and organizing work were inclined to direct and limit competence.

However, these kinds of methods cannot completely control the development of professional competence. The competences of employees cannot be owned by a company, although work organizations are important sites for professional learning. The methods do not allow absolute dominance and the people under control are able to cope with it and even sidestep it. In addition, restricting the specialization of professionals might turn into a shortage of specialized labor. Changes in the market might make yesterday's recruiting criteria inappropriate if, for example, customers require high-quality products, which can only be produced by specialized staff.

\section{Management and shared interest}

Governance is based on not only top-down management, but also bottom-up communication and network-based power practicing. However, management has best opportunities for power practicing, which is due to the connection between power relations and institutions in working life. Management is located in knots of institutionalized relations, which reinforces its opportunities to exercise power. Relations of power and historically shaped institutionalized relations in production touch and support each other (Foucault 1980, pp. 139-142). Management is legitimated to organize professional work and control professional employees, but collaboration in decision-making with professional employees is necessary for the purpose of efficiency and quality of work. Management takes into account the possibility of resistance and acknowledges that compelling is not appropriate.

In the new media company, the approval from the professional employees as regards the organization of work was necessary, although the initiative originated from the stockholders and management. The professionals approved the pattern and complied with it. The staff supported the goal for profitability and standardization of working methods because they considered it reasonable, particularly in the uncertain environment of new media business. One designer said, 'I know the financial aspect well enough. The budget defines how to work' (male, audio-video designer). In the late 1990s, new media business was considered to produce useless entertainment, and the companies were not considered respectable business firms. However, the professionals interviewed emphasized the sensible management in the company: striving for standardized working hours, competent professional work, useful and proper products for customers, and profitable business. One example of this acknowledgement by staff follows:

'Compared to our competitors, we are to a much lesser degree in newspapers and magazines. It is a considered decision: this is not hype but sensible and useful work. Focus on doing - not talking.' (male, programmer). 
In work organizations, mutual understanding and agreement concerning principles, targets, and practices is the basis for governance, because everyone is dependent on each other when striving for her or his own objectives and shared aims (see Hosking and Morley 1991, pp. 66-70). Professional employees have work-related interests at work sites. The shared objective supplies the continuity for work and economics by which employees, managers, and stockholders profit. However, the consensus is always incomplete, because the employees, managers, and stockholders have also divergent and even contradictory interests (Parker 2000, pp. 85-90). Although the new media professionals supported the goals of profitability and standardization, they were not satisfied with the poor possibilities for high-quality professional performance.

\section{Self-governance and professional identity}

Governance was realized, in addition to the collective actions, within professionals' selfgovernance, in other words, in self-control and in self-design. The most crucial form of control was the professionals' responsibility for their own duties. The responsibility was accompanied with independence and freedom from "bossing," which the professionals appreciated.

'The management is flexible, provides liberties, but initiative-taking and responsibility are required as well. Management trusts the professionals' (male, programmer).

Individuals adjust themselves to work sites by assimilating their own interests into the organization and settling themselves in social relations and spaces (Foucault 1977, pp. 28, 184). Thus, external control is not needed as professional employees' self-governance is efficient. Standardized control practiced by superiors or by nonhuman control methods (for example, electronic instruments) treats all employees in the same way and cannot take into account context-related issues as self-governance. Self-governance is, however, uncertain, because employees might have interests, which do not match the objectives of the work organization.

The important dimension of self-governance is designing oneself. Nikolas Rose (2000, p. 91) argues that the significance of working life for employees has extended from the field of economy into psychology and the work organizations are crucial arenas for shaping self. In a society highlighting the significance of paid work, designing professional identity is particularly important. Professional organizations provide a socially and culturally appropriate environment for self-shaping. Designing identity is based on constructing memberships to adequate professional disciplines and groups, which is often carried out by standing out from disciplines and groups regarded inferior (see Rose 2000, p. 46).

The professional programmers and content providers reinforced their professional identity by underlining the special knowledge body and competence of the professional group; they reinforce their professional identity by emphasizing the difference to other groups. They claimed that the team members having different professional competence were unable to understand their particular professional vision.

'When the project manager and scriptwriter make the draft, it is based on a written text, because it is produced applying their professional competence. They don't recognize the aesthetic point of view: it is not visual; it is an illustrated text.' (male, graphic designer). 
A strong disciplinary-specific approach in team work caused problems in interaction with other professional groups. In the new media company, the strict division of labor was realized as follows. The strict boundaries of labor division were not crossed. The division was supposed to prevent conflicts: 'We all have our own duties and tasks and I think it makes it work. You take care of your own business and there's no conflict' (female, graphic designer). However, the interviewed professionals often reported conflicts between the employees representing different professional approaches. 'Conflicts are common, for example between scriptwriters and programmers. The contents do not fit in technology.' (female, scriptwriter)

The negative consequences of the strict division of professional territories and struggle for professional status were poor interaction and conflicts between professional groups. The phenomenon is not new: according to the other studies dealing with IT companies, strict labor division weakens the opportunities for interaction and colleagues are considered to be an obstacle to creative work (Kolehmainen 2001, p. 62). The phenomenon is related to the institutionalization of work organizations: labor division and professional territories are established. Professional employees might have independence in their territories but a minor influence on more important issues in production, which presume collaborated work processes.

\section{Tension between creativity-based identity and standardization}

The programmers and content providers considered creativity to be the core of their professional identity. For the content providers, it was an artistic creativity, which had been developed in the universities and colleges and in constant engagement in the arts. The programmers referred to a technical and intellectual problem-solving competence when defining their creativity. The interviewed professionals complained about the poor opportunities to creative work. The strict time schedules and the requirements of the customers standardized the work:

\footnotetext{
'It would be nice to say that my work demands creativity. It does not: this is just a job to do. It is providing standardized solutions; the professional competence is that you can do proper work. About a proportion of $10 \%$ of the total work provides an opportunity for creativity, but most often it is updating Internet sites. And the customer companies strictly comply with their graphic standards.' (male, graphic designer)
}

There was a tension in the programmers' and content providers' work: the relationship between the creativity-based identity and the standardization or work. Their professional ambition often ranged above the limits set by the conditions. Following the strict schedule often caused poor performance and they felt that it damaged their professional prestige. The solutions were to lower their professional standards or to work overtime: 'I could perform my job in eight hours, but with no opportunity for satisfaction with the result.' (male, audio-video designer). They expressed the need for more creative work and had dreams of taking a break for artistic experiments with no financial constraints. In the beginning of the 2000s, the standardization of work was a common phenomenon in ICT companies due to the institutionalization of business activities (see Engeström and Ilmarinen 2001; Koistinen 2007; Kolehmainen 2001, p. 37). However, 
the standardization method is sometimes inappropriate as regards changing markets and demands; professionals' creative approach might fit better in markets when standardized products no longer satisfy customers.

\section{Summary and conclusions}

The early 2000s was the turning point in new media business, as the companies started to become business-like and grow. The goal of profit-making was implemented in work organization. The core concept "governance" represents the mode of thinking and action related to the objectives of efficiency and economy. The objectives of effectiveness and economy lead to streamlining and financial management and, at the individual level, the way of thinking and the related pattern for action is self-governance.

Financial management and streamlining promoted standardizing the professional work and competence. The professional work was standardized with the uniform patterns and working methods and setting tight limits for resources. The management supported intra-organizational training and collegial learning in order to standardize the quality of performance. The management also strove to control the competence, because specialized expertise would provide the employees with better opportunities for new jobs. Organizing work in temporary teams limited the opportunities for professional specialization.

Professional identity was both strengthened and weakened as a consequence of streamlining and financial management. The division of labor promoted professional territories and identities and set boundaries between the professional groups. The standardization of work limited the opportunities for creative work, which the professional employees considered important for their professional identity. In addition, the limited resources and the strict schedule did not provide professionals with opportunities for multi-disciplinary team work, which decreased learning opportunities.

The tension between standardization of work and needs for discretion in professional work was challenging and problematic in the case study company, and the tension has not yet been solved. A general managerial strategy in highly competitive environments is to promote patterns, which remove uncertainty and increase control, for example, quality systems. The consequences of expansion of knowledge work and labor force with higher education are mass production of professional services and the tight competition as knowledge-specific services are becoming globally distributed. Because of this tendency, the standardized quality of performance and streamlined work organization are promoted. However, professional experts still need a sufficient degree of freedom, because objectives, methods, and environments of knowledge work are complex and professional discretion is necessary. Thus, a key question when organizing professional work is how to maintain a balance between standardization and discretion in professional work.

\section{References}

Abbott, A. (1988) The system of profession. An Essay on the Division of Expert Labour. Chicago: The University of Chicago Press. 
Alvesson, M. (1995) Management of Knowledge-Intensive Companies. New York: Walter de Gruyter.

Beirne, M., Ramsay, H. and Panteli, N. (1998) 'Developments in computing work: control and contradiction in the software labour process'. In P. Thompson and C. Warhurst (eds.) Workplaces of the Future. London: Macmillan: 142-162.

Casey, C. (1995) Work, Self and Society: After Industrialism. London, New York: Routledge.

Castells, M. (1996) The Rise of the Network Society. Oxford: Blackwell.

Christopherson, S. (2002) 'Project work in context: regulatory change and the new geography of media'. Environment and Planning Vol. 34(11): 2003-2015.

Clements, P., Jones, L., Northrop, L. \& McGregor, J. (2005) 'Project management in asoftware product line organization. IEEE Software Vol. 22(5): 54-62.

Dean, M. (1999) Governmentality. Power and Rule in Modern Society. London: Sage.

Depickere, A. (1999).'Managing virtual working'. In P. Jackson (ed.) Virtual Working. Social and Organisational Dynamics. London: Routledge, 99-120.

Engeström, J. and Ilmarinen, V. (2001) 'Innovaatiot tietämyksen kantajina: osaamisen johtaminen Satama Interactivessa'. (Innovations and knowledge: managing competence in Satama Interactive) In J. Engeström and V. Ilmarinen (eds.) Osaamisen jobtaminen muutoksessa. Ideoita ja kokemuksia toisen sukupolven knowledge managementin kehittelyyn. http://www.mol.fi/mol/fi/99_pdf/fi/03_tutkimus_ja_kehittaminen/02_tykes/05_ aineistopankki/julkaisut/jvirkkunen.pdf\#page $=137$

Foucault, M. (1977) Discipline and Punish: The Birth of the Prison. London: Allen Lane.

Foucault, M. (1979) 'Governmentality'. Ideology and Consciousness Vol. 6: 5-21.

Foucault, M. (1980) Power/knowledge. Selected Interviews \& Other Writings. In C. Gordon (ed.) New York: Pantheon Books.

Foucault, M. (1991) ‘On governmentality’. In G. Burchell, C. Gordon and P. Miller (eds.) The Foucault Effect: Studies in Governmentality. Chicago: The University of Chicago Press: $87-105$.

Garcia, S. (2005) 'How Standards Enable Adoption of Project Management Practice.' IEEE Software Vol. 22(5): 22-29.

Grint, K. (1998) The Sociology of Work, 2nd Edition. Cambridge: Polity Press.

Haapakorpi, A. (2009) Sulkeuman ja neuvottelun ehdoilla - asiantuntija-aseman rakentuminen työelämässä. (Closure and Negotiation - Constructing Professional Position in Working Life) Väitöskirja (PhD Thesis). Helsingin yliopisto, sosiologian laitos (University of Helsinki, Department of Sociology). Yliopistopaino.

Hosking, D.-M. and Morley, I. (1991) A Social Psychology of Organizing. People, Processes and Contexts, Prentice Hall, NJ: Harvester Wheatsheaf.

Jackson, N. and Carter, P. (1998) 'Labour as dressage'. In A. McKinley and K. Starkey (eds.) Foucault, Management and Organization Theory. London, Thousand Oaks, New Delhi: Sage: 49-65.

Kangasoja, J. and Koistinen, K. (1997) Learning to Survive: How does a Small Multimedia Company Learn to Master the Production Process? In: Nordic-Baltic Conference on Activity Theory. 1st Nordic-Baltic Conference on Activity Theory, Helsinki Feb 7-9,1997, University of Helsinki, 12-15.

Karn, J. (2008) 'An Ethnographic Study of Conflict in Software Engineering Teams'. Journal of Information, Information Technology \& Organizations Vol. 3: 106-133.

Kivimäki, R. (2007) 'In search of boundaries: changing boundaries in and through teleworking'. In T. Heiskanen and J. Hearn (eds.) Information Society and the Workplace. Spaces, Boundaries and Agency. Routledge Studies in Technology, Work and Organizations: 178-192.

Koistinen, K. (2007) Kaveriporukasta liiketoiminnaksi. Tuotannon häiriöt ja organisaation oppiminen nopeasti muuttuvassa yrityksessä. ( $\mathrm{PhD}$ Thesis). Helsingin yliopisto. 
Kasvatustieteen laitoksen tutkimuksia 213. Helsinki. http://www.doria.fi/bitstream/ handle/10024/12003/kaveripo.pdf

Kolehmainen, S. (2001) Work Organisation in High-Tech IT Firms, University of Tampere Work Research Centre, Reports 62/2001, Sitra Reports series 14/2001.

Kolehmainen, S. (2007) 'The dynamics of control and commitment in IT firms'. In T. Heiskanen and J. Hearn (eds.) Information Society and the Workplace. Spaces, Boundaries and Agency. Routledge Studies in Technology, Work and Organizations: 83-102.

Korvajärvi, P. (2007) 'Women and technological pleasure at work?' In T. Heiskanen and J. Hearn (eds.) Information Society and the Workplace. Spaces, Boundaries and Agency. Routledge Studies in Technology, Work and Organizations: 125-142.

Lawler III, E.E. (2000) Rewarding Excellence. Pay Strategies for the New Economy. San Francisco, JosseyBass.

McKinley, A. and Starkey K. (1998) Foucault, Management and Organization Theory. London, Thousand Oaks, New Delhi: Sage.

Mintzberg, H. (1989) Mintzberg on Management. Inside Our Strange World of Organizations. New York: The Free Press.

Niemelä, J. (2008) 'Ryhmätyö ja kokemukset työelämän laadusta Suomessa.' (Team work and experience in work life quality) Työelämän tutkimus 6(2): 129-146.

Parker, M. (2000) Organizational Culture and Identity. Unity and Division at Work. London, Thousand Oaks, New Delhi: Sage.

Pohto, P. and Wiren, L. (2001) Uusmedia aikuistumisen kynnyksellä. Raportti uusmediatoimialasta Suomessa 2000. (Report on the new media industry in Finland 2000). LTTTutkimus, Elektronisen kaupan instituutti EKI. Kirjapaino Tieto. Helsinki.

Pratt, A., Gill, R. and Spelthann, V. (2007) 'Work and the city in the e-society. A critical investigation of the socio-spatially situated character of economic production in the digital content industries in the UK.' Information, Communication \& Society Vol. 10(6): 922-942.

Rose, N. (2000) Powers of Freedom. Re-framing Political Thought. Cambridge: Cambridge University Press.

Del Rosso, C. (2009) 'Comprehend and analyze knowledge networks to improve software evolution.' Journal of Software Maintenance \& Evolution: Research \& Practice Vol. 21(3): 189-215.

Scott, W. R. and Davis, G. F. (2007) Organizations and Organizing. Rational, Natural, and Open System Perspectives. Pearson International Edition.

Strauss, A. (1990) Basics of Qualitative Research: Grounded Theory Procedures and Techniques. Newbury Park, CA: Sage Publications.

Strauss, A. and Corbin, J. (1998) Basics of Qualitative Research. Techniques and Procedures for Developing Grounded Theory, 2nd Edition. Thousand Oaks, CA: Sage.

Tarkka, M. (2002a) 'Mediakulttuurin kotimainen toimiala.' (The Finnish Industry of Media Culture.) In M. Tarkka and T. Mäkelä (eds.) Uusi mediakulttuuri innovaatioympäristönä. Kotimainen ja kansainvälinen tutkimus. (New Media Culture as a Innovation Environment. Domestic and International Research). Sisältötuotanto-työryhmän väliraportti 7.Sisältötuotanto-työryhmän väliraportti 7. Mediakulttuuriyhdistys m-cult ry. Helsinki: 19-34.

Tarkka, M. (2002b) 'Teknologiakehityksen kulttuurinen käänne - tutkimus- ja kehitystyön uudet suunnat.' (The Cultural Change in Technology development.) In M. Tarkka and T. Mäkelä (eds.) Uusi mediakulttuuri innovaatioympäristönä. Kotimainen ja kansainvälinen tutkimus. (New Media Culture as a Innovation Environment. Domestic and International Research). Sisältötuotanto-työryhmän väliraportti 7. Mediakulttuuriyhdistys m-cult ry. Helsinki: 89-98. 
Tidd, J., Bessant, J. and Pavitt, K. (1997) Managing Innovation. Integrating Technological, Market and Organisational Change. Chichester: John Wiley \& Sons.

Townley, B. (1998) 'Beyond good and evil.' In A. McKinlay and K. Starkey (eds.) Foucault, Management and Organization Theory. From Panopticon to Technologies of Self. Thousand Oaks, CA: Sage: 191-210.

Virtanen, M. (1987) Tehtaasta studioon. (From factory to studio). Helsinki: Hanki ja jää.

\section{End notes}

${ }^{1}$ The categories are not clear-cut as in the empirical studies; both these perspectives are often included. The emphasis of the perspective makes the difference.

2 The definition for an organizational form is the following: 'A social structure created by individuals to support the collaborative pursuit of specified goals.' (Scott and Davis 2007, pp. 11, 131).

${ }^{3}$ Strauss and Corbin emphasized the significance of data as the source of theoretical work in their former writings (1990). Later, they admitted that it is not possible to construct theories only on the basis of data analysis. Theories are constructed with analysis benefiting both ready-made theories and definitions and concepts emerging from the data (1998, p. 43).

The research was funded by the Finnish Work Environment Fund. 